CALCULATED VALUES 



\title{
CALCULATED VALUES
}

Finance, Politics, and the Quantitative Age

\author{
WILLIAM DERINGER
}

\author{
I \\ Harvard University Press \\ Cambridge, Massachusetts \\ London, England \\ 2018
}


Copyright (@) 2018 by the President and Fellows of Harvard College All rights reserved

Printed in the United States of America

\section{First printing}

\section{Library of Congress Cataloging-in-Publication Data}

Names: Deringer, William, 1984- author.

Title: Calculated values : finance, politics, and the quantitative age/ William Deringer.

Description: Cambridge, Massachusetts : Harvard University Press, 2018. |

Includes bibliographical references and index.

Identifiers: LCCN 2017034530 | ISBN 9780674971875 (alk. paper)

Subjects: LCSH: Great Britain-Politics and government-I603-17I4. |

Great Britain-Politics and government—-18th century. | Quantitative

research-Great Britain-History. | Numerical calculations—History. |

Numerical calculations_-Political aspects. | Persuasion (Rhetoric)—Political aspects.

Classification: LCC DAI8 .D425 2018 | DDC 941.06-dc23

LC record available at https://lccn.loc.gov/2017034530

Jacket image: The South Sea Bubble, a Scene in 'Change Alley in 1720. Engraving by J. Carter after painting by Edward Matthew Ward. Courtesy of the Library of Congress.

Jacket design: Annamarie McMahon Why 
For Susanna

(and G!) 
